\title{
Maternal natural killer cell immunoglobulin receptor genes and human leukocyte antigen-C ligands influence recurrent spontaneous abortion in the Han Chinese population
}

\author{
NING SU ${ }^{1,2}$, HONGDAN WANG $^{2}$, BOWEI ZHANG $^{3}$, YIQING KANG $^{3}$, QIANNAN GUO $^{2}$, \\ HAI XIAO ${ }^{2}$, HECAI YANG ${ }^{3}$ and SHIXIU LIAO ${ }^{2}$
}

\begin{abstract}
${ }^{1}$ Department of Obstetrics and Gynecology, People's Hospital of Zhengzhou University; ${ }^{2}$ Henan Medical Genetics Institute, Henan Provincial People's Hospital, Zhengzhou, Henan 450003; ${ }^{3}$ International Office for Research and Development, Henan Red Cross Blood Center, Zhengzhou, Henan 450000, P.R. China
\end{abstract}

Received April 25, 2017; Accepted October 30, 2017

DOI: 10.3892/etm.2017.5406

\begin{abstract}
The underlying mechanism of recurrent spontaneous abortion (RSA) has remained elusive for many years. Several previous studies have suggested that the killer cell immunoglobulin receptor (KIR) gene family is associated with RSA, however, it is not clear exactly how. The present study detected KIR and human leukocyte antigen-C (HLA-C) genes in 110 Han Chinese women with unexplained RSA and 105 Han Chinese healthy females. The aim of the present study was to determine if certain genotypes were more susceptible to the occurrence of miscarriage. The frequency of KIR genes and different KIR haplotypes in the 2 groups demonstrated no statistical differences. However, in women who had miscarried $\geq 3$ times, the frequency of KIR3DL1 was significantly reduced and the BB haplotype frequency was significantly higher compared with the control group. HLA-C2C2 was significantly increased in the KIR AB and KIR BB groups in the RSA groups compared with the control group. The women in the RSA group who had a homozygous HLA-C2C2 had a significantly higher frequency of the 2DS1 gene compared with the control group. The reduction of inhibitory gene and increased activation combinations may induce the activation of uterine natural killer cells, which may reduce the probability of fetal survival. To the best of our knowledge, the present study is the first report demonstrating the association between maternal KIR and HLA-C genes and RSA in women of a Han Chinese ethnicity. The present study revealed that females
\end{abstract}

Correspondence to: Dr Shixiu Liao, Henan Medical Genetics Institute, Henan Provincial People's Hospital, 7 Weiwu Road, Zhengzhou, Henan 450003, P.R. China

E-mail: ychslshx@126.com

Key words: recurrent spontaneous abortion, uterine natural killer cells, killer cell immunoglobulin receptor, human leukocyte antigen-C, threshold effect who miscarry $\geq 3$ times may be used as selection criteria for RSA and so may exhibit higher research value.

\section{Introduction}

Recurrent spontaneous abortion (RSA) is defined by the American Society for Reproductive Medicine (ASRM) as $\geq 2$ consecutive spontaneous abortions, whereas the Royal College of Obstetricians and Gynecologists and the European Society for Human Reproduction and Embryology, specify it as the loss of $\geq 3$ consecutive fetuses prior to 24 weeks of pregnancy with the same partner. Statistically, $15-25 \%$ of pregnancies result in miscarriage and $<5 \%$ of women will experience two miscarriages, only $1 \%$ of women will experience the loss of a fetus $\geq 3$ times $(1,2)$. The causes of RSA are considered to include cytogenetic abnormalities, anatomic irregularities, endocrine disorders, infection, autoimmunity, atypical blood clotting, sperm quality and environmental factors (2). However, in $\sim 50 \%$ of RSA cases no clearly defined etiology is identified (3).

During pregnancy fetal trophoblast cells infiltrate into the maternal uterine blood vessels and release blood into the intervillous space (4). The outer layer of the chorionic villi (syncytiotrophoblast) is bathed directly in maternal blood, which enables the fetus to easily acquire nutrients (5). However, the exposure of trophoblast cells may lead to potential allogeneic immune responses by the mother. Typically, uterine immune responses allow the placenta to acquire maternal supplies and also prevent excessive invasion (4). Disruption of the normal balance between the itinerant trophoblast cells and the uterine tissues they colonize during placentation, may result in various clinical problems (4). The hypothesis that maternal-fetal immune disorders lead to miscarriage may be traced back to the 20th century when Medawar postulated that the fetus may be considered as an allograft to the mother, and that the absence of a maternal immune response is what allows embryonic implantation (6).

Natural killer cells (NKs) are the third largest granular cells and they account for $10-15 \%$ of the total lymphocytes in the blood (7). NKs are activated by external stimuli and 
they serve a vital role in immune regulation and defense (5). A number of uterine NKs (uNKs) gather in the endometrium prior to placentation and they make up $75 \%$ of all uterine decidua lymphocytes in early pregnancy (8). At 20 weeks of pregnancy the uNKs begin to decline and they disappear by the third trimester (9). Tissue NKs differ from circulating NKs as their phenotype and function are modified by the local microenvironment $(10,11)$. A total of $90 \%$ of peripheral blood NK cells (pbNKs) are CD56 ${ }^{\mathrm{dim}}$ cells, which highly express CD16 and possess clear cytotoxic activity (12). uNKs are primarily CD56 ${ }^{\text {bright }}$ cells, which lack cytotoxicity and instead secrete various cytokines, which serve an important role in adjusting the invasion of trophoblastic cells $(13,14)$.

NK activity depends on the integration of signals from numerous germline-encoded activating and inhibitory receptors, which are primarily from three families: C-type lectin-like receptors, immunoglobulin (Ig)-like transcripts and killer cell Ig-like receptors (KIRs) $(15,16)$. KIRs are encoded by an array of highly polymorphic genes located on chromosome 19q13.4, which produce wide variations in KIR structure and combination (17). KIRs are classified according to their structure and function. Each KIR molecule consists of two or three extracellular Ig domains (2D and 3D molecules, respectively), a transmembrane section and a short (S) or long (L) intracellular tail (18). Each inhibitory KIR receptor contains an immune receptor tyrosine inhibition motif in its cytoplasmic domain, which may interact with SH2-containing protein-tyrosine phosphatase- 1 in the cytoplasm, and inhibit the activation of the NK cell (19). Each activating KIR, possesses a short charged cytoplasmic tail, which combines with the immune receptor tyrosine activation sequence or DAP12 adapter protein, thus enhancing activation signals and gene expression in NKs $(16,20)$. To the best of our knowledge, 15 KIR gene loci and two pseudogenes have been identified to date, among which a marked linkage disequilibrium exists (21). Two common haplotypes, designated A and B, have been defined based on the number of KIR genes present. The A haplotype is less variable and is recognized by the presence of a minimum of 6 inhibitory receptor genes (KIR-2DL1, -2DL3, -2DL4, -3DL1, -3DL2 and -3DL3) as well as the only activating receptor gene (KIR2DS4) (22). The B haplotype has a more variable and numerous gene content, which differs due to the various possible combinations of activating receptor genes (23). There are three distinct groups of KIR genotype in humans, which are KIR-AA, -AB and -BB. At present, $>550$ different KIR genotype IDs have been described, which has greatly enriched the understanding of the KIR gene family (allelefrequencies.net/kir6001a.asp; update in 2015).

KIRs combine with human leukocyte antigen (HLA) ligands on the surface of target cells and are closely associated with virus infection, malignancy, autoimmune diseases, organ transplantation and the process of pregnancy (24-27). In recent decades, an increasing number of studies have indicated that KIRs may be associated with RSA. Certain previous studies consider a maternal KIR-AA homozygous genotype as a protective factor, which inhibits the activation of uNKs and prevents the fetus from being rejected (28-30). However, others have reported that the KIR-B haplotype promotes uNK activation and cytokine secretion, which is conducive to trophoblastic cell implantation into the endometrium and thus promotes a successful pregnancy $(31,32)$. It is possible that some specific combinations of KIR genes may serve a role in the autoimmune mechanisms underlying recurrent miscarriage. Individuals from different regions and ethnic groups often have large differences in the frequencies of KIR genotypes. The frequency of KIR-AA ranges from $1.5 \%$ in the Australian aborigines to $67.9 \%$ in the China Yunnan Province $\mathrm{Nu}(33,34)$. As numerous factors may lead to miscarriage, it is necessary to consider these while analyzing the association between KIR and spontaneous abortion. Considering the geographical and ethnic differences that are observed in the KIR and HLA-C genes, the present study investigated only those of a Han Chinese ethnicity. The current study detected the KIR and HLA-C genes of 110 unexplained RSA and 105 healthy females. The aim of the present study was to determine if certain KIR genotypes influence the occurrence of spontaneous miscarriage.

\section{Materials and methods}

Study subjects and samples. In the present study the ASRM definition of RSA (as defined above) was adhered to. Couples with $\geq 2$ recurrent spontaneous miscarriages prior to 20 weeks of pregnancy and no live births were recruited from Henan Provincial People's Hospital (Henan, China) between September 2015 and September 2016. The parental chromosomes were karyotyped. At day 3, the follicle-stimulating hormone, luteinizing hormone and testosterone levels were measured in the females in a clinical laboratory at the Henan Provincial People's Hospital (Henan, China) and the results were reported to us, an ultrasound examination or hysteroscopy was performed prior to the current study, semen quality was measured and a thyroid function test was performed in order to rule out abnormal thyroid function, which is related to miscarriage [thyroid stimulating hormone (TSH), triiodothyronine (T3), thyroxine (T4), free triiodothyronine (FT3), free thyroxine (FT4), anti-thyroid peroxidase antibodies (anti-TPO) and antithyroglobulin antibody (anti-TG)] (35). The blood glucose level and level of immune antibodies, including antiphospholipid, endometrial, sperm, anti human chorionic gonadotropin, anti zona pellucida and anti ovarian antibodies were measured and a TORCH-IgM (TOX-IgM, RV-IgM, CMV-IgM and HSV-IgM) screen was performed. Studies have demonstrated that TORCH-IgM antibodies have a strong association with the occurrence of RSA (36). Mycoplasma and chlamydia infection were tested for and blood coagulation function (PT, ARTT, FIB, TT) and D-dimer tests were performed identify if patients met inclusion criteria. The hypercoagulation of blood is associated with the occurrence of miscarriage (37).

Of the 188 patients tested who had normal chromosomes, 78 were excluded because the suspected reasons for their miscarriage were identified. Consequently, there were 110 couples of Han Chinese ethnicity that met the aforementioned conditions and were recruited into the experimental (RSA) group (age, 20-39 years). Each of the females enrolled in the study had no history of poisonous or teratogenic chemical exposure, lived a healthy lifestyle and had never fallen pregnant with a previous partner. The control group consisted of 105 healthy females (age, 19-39 years) recruited from the Henan Red Cross Blood 
Center between November 2015 and September 2016, who had given birth to a minimum of 1 healthy child and had no history of miscarriage. The 2 groups had the same ethno-geographic origin and there were no differences in ages. All participants were informed about the study and written informed consent was obtained. Ethical approval for the present study was obtained from the Board of Ethics Committee of the Henan Provincial People's Hospital. Blood samples $(5 \mathrm{ml})$ taken from all female participants were preserved in tubes containing EDTA at $4^{\circ} \mathrm{C}$ prior to genetic evaluation.

DNA isolation. Maternal genomic DNA was isolated from $5 \mathrm{ml}$ of blood using the TIANamp Genomic DNA kit (Tiangen Biotech Co., Ltd., Beijing, China). The quantity and quality of the DNA samples was detected using a NanoDrop ${ }^{\mathrm{TM}} 2000$ spectrophotometer at wavelengths of 230, 260 and $280 \mathrm{~nm}$ (Thermo Fisher Scientific, Inc., Waltham, MA, USA). The experiment procedure was conducted according to the manufacturer's protocol.

KIR genotyping. KIR genotyping was performed on maternal genomic DNA using a KIR Genotyping kit (cat. no. 54410D; Invitrogen; Thermo Fisher Scientific, Inc.), which detected the presence or absence of KIR genes using polymerase chain reaction (PCR)-sequence specific primers. Formulations of locus specific primers from the kit were used to amplify genomic DNA. The reaction buffer was mixed with the genomic DNA sample and Taq DNA polymerase (cat. no. M8296; Promega Corporation, Madison, WI, USA) in a 96-well thermal tray. Thermocyling was performed as follows: Initial denaturation of $95^{\circ} \mathrm{C}$ for $1 \mathrm{~min}$; 30 cycles of denaturation at $94^{\circ} \mathrm{C}$ for $20 \mathrm{sec}$, annealing at $63^{\circ} \mathrm{C}$ for $20 \mathrm{sec}$ and extension at $72^{\circ} \mathrm{C}$ for $90 \mathrm{sec}$. $2 \%$ agarose gel preparation was performed as follows: $2 \mathrm{~g}$ of agarose powder was poured into a $250 \mathrm{ml}$ conical flask and $100 \mathrm{ml}$ of $0.5 \mathrm{X}$ tetrabromoethane was dissolved in the flask. The microwave oven was heated to boiling and ethidium bromide (cat. no. 15585011; Thermo Fisher Scientific, Inc.) $(6 \mu \mathrm{l})$ was added. The flask was shaken and the mixture was poured into the template and cooled for $30 \mathrm{~min}$. When the thermocycling process was complete, $5 \mu \mathrm{l}$ PCR products were loaded onto a $2 \%$ agarose gel using a pipette. Electrophoresis was carried out in the electrophoresis tank, which was filled with $0.5 \mathrm{X}$ tetrabromoethane. The gel was run at a voltage of $150 \mathrm{~V}$ for $20 \mathrm{~min}$. Following electrophoresis, the gel was placed under UV light to observe and record the results.

HLA-C genotyping. For HLA-C1 and-C2 genotyping, the same primers were used as previously reported by Tajik et al (38). The PCR system in each reaction was $12 \mu \mathrm{l}$ in total [60 ng genomic DNA $(1 \mu \mathrm{l}), 2 \mathrm{X}$ Taq PCR Master mix (Bio Basic, Inc., Markham, ON, Canada) (5 $\mu \mathrm{l})$, nuclease-free water (5 $\mu \mathrm{l})$, forward $(0.5 \mu \mathrm{l})$ and reverse $(0.5 \mu \mathrm{l})$ primers]. PCR conditions were: Initial denaturation for $2 \mathrm{~min}$ at $94^{\circ} \mathrm{C} ; 10$ cycles of $10 \mathrm{sec}$ denaturation at $94^{\circ} \mathrm{C}$ and $60 \mathrm{sec}$ annealing and elongation at $65^{\circ} \mathrm{C} ; 20$ cycles of $10 \mathrm{sec}$ denaturation at $94^{\circ} \mathrm{C}, 50 \mathrm{sec}$ annealing at $61^{\circ} \mathrm{C}$ and $30 \mathrm{sec}$ elongation at $72^{\circ} \mathrm{C}$; with a final extension step at $72^{\circ} \mathrm{C}$ for $10 \mathrm{~min}$. When the thermocycling process was complete, a total of $6 \mu$ l loading buffer (cat. no. B648314; Sangon Biotech Co., Ltd., Shanghai, China) was mixed with the amplification products and electrophoresed on
$2 \%$ agarose gels. $2 \%$ agarose gel preparation was performed same as the above method and ethidium bromide was used as a DNA stain. The gel was run at a voltage of $150 \mathrm{~V}$ for $25 \mathrm{~min}$. Following electrophoresis, the gel was placed under UV light (WD-9403C; Beijing Liuyi Biotechnology Co., Ltd., Beijing, China) to observe and record the results.

Statistical analysis. The percentage of KIR and HLA-C genes in the present study was determined by direct counting. The frequency of the two populations of KIR haplotypes (A and $\mathrm{B}$ ) and HLA-C alleles (C1 and C2) were obtained using the Hardy-Weinberg principle $\left(p^{2}+2 p q+q^{2}=1\right)(39)$. All data were statistically analyzed using Chi-square analysis, Pearson Chi-square continuity correction and Fisher's exact test, on SPSS version 17 software (SPSS, Inc., Chicago, IL, USA). $\mathrm{P} \leq 0.05$ was considered to indicate a statistically significant difference. Data are presented as numbers and percentages. Odds ratios (ORs) and 95\% confidence intervals (CIs) were calculated.

\section{Results}

Carrier frequency of KIR genes in the RSA and control group. A total of 19 KIR genes were genotyped in all participants: 2DL1, 2DL2, 2DL3, 2DL4, 2DL5A, 2DL5B, 2DS1, 2DS2, 2DS3, 2DS4FUL, 2DS4DEL (2DS4 allele with a 22 base pair deletion), 2DS5, 3DL1, 3DL2, 3DL3, 3DS1, 2DP1, 3DP1FUL and 3DP1DEL (absence of exon 2 and its flanking intron sequences) (Table I and Fig. 1). The 4 framework genes (conservative gene positions fixed and present in each person's KIR gene), KIR2DL4, 3DL2, 3DL3 and 3DP1FUL or 3DP1DEL were present in all of the samples. The KIR pseudogene KIR2DP1 was present in all samples from the normal group, but only $99.1 \%$ of the samples from the experimental RSA group. In all participants, it was identified that compared with the activating KIR genes, the inhibitory KIR genes had aT higher frequency. Among the inhibitory KIR genes, KIR2DL1 demonstrated the highest frequency, as it was present in 99.1 and $100 \%$ of the experimental and control groups, respectively. The other most frequent inhibitory KIR genes were KIR2DL3 and KIR3DL1, which were present in $\geq 91.8 \%$ in each group. Apart from KIR2DS4 positive genotypes (KIR2DS4FUL, KIR2DS4DEL or combined genotypes), the frequency of the activating genes was $<40 \%$. KIR2DS2 demonstrated the lowest observed carrier frequency of any activating gene, as it was present in $18.2 \%$ of the experimental group and $16.2 \%$ of the control group. No statistically significant differences were identified between the frequency of each KIR gene in the experimental group and the control group. Additionally, no significant differences were identified in the frequency of the inhibitory and activated KIR genes in each group.

The experimental group was subsequently divided into 2 smaller groups depending on the number of miscarriages undergone by each participant. The frequency of the KIR3DL1 gene was significantly reduced in women who had aborted $\geq 3$ times compared with the control group $(\mathrm{P}=0.025$; OR, 0.277; CI, 0.085-0.904; Table II). However, there was still no significant difference identified between the frequency of the inhibitory and activating KIR genes in these 2 groups. 
Table I. Comparison of the frequency of KIR genes in the RSA $(n=110)$ and control $(n=105)$ groups.

\begin{tabular}{|c|c|c|c|c|c|c|c|c|}
\hline & & \multicolumn{2}{|c|}{ RSA group } & \multicolumn{2}{|c|}{ Control group } & \multirow[b]{2}{*}{ P-value } & \multirow[b]{2}{*}{ Odds ratio } & \multirow[b]{2}{*}{$95 \%$ confidence interva } \\
\hline \multicolumn{2}{|c|}{ KIR gene } & $\mathrm{n}$ & $\%$ & $\mathrm{n}$ & $\%$ & & & \\
\hline Inhibitory & 2DL1 & 109 & 99.1 & 105 & 100.0 & 1.000 & 0.991 & $0.973-1.010$ \\
\hline Inhibitory & 2DL2 & 21 & 19.1 & 17 & 16.2 & 0.591 & 1.221 & $0.589-2.532$ \\
\hline Inhibitory & 2DL3 & 108 & 98.2 & 105 & 100.0 & 0.497 & 0.982 & $0.956-1.008$ \\
\hline Inhibitory & 2DL4 & 110 & 100.0 & 105 & 100.0 & 1.000 & - & - \\
\hline Inhibitory & 2DL5A & 41 & 37.3 & 37 & 35.2 & 0.757 & 1.095 & $0.615-1.950$ \\
\hline Inhibitory & 2DL5B & 10 & 9.1 & 10 & 9.5 & 0.922 & 0.954 & $0.367-2.477$ \\
\hline Activating & 2DS1 & 44 & 40.0 & 40 & 38.1 & 0.783 & 1.083 & 0.614-1.912 \\
\hline Activating & 2DS2 & 20 & 18.2 & 17 & 16.2 & 0.708 & 1.151 & $0.552-2.401$ \\
\hline Activating & 2DS3 & 26 & 23.6 & 23 & 21.9 & 0.774 & 1.102 & $0.568-2.135$ \\
\hline Activating & 2DS5 & 31 & 28.2 & 23 & 21.9 & 0.304 & 1.401 & $0.736-2.666$ \\
\hline Inhibitory & 3DL1 & 101 & 91.8 & 101 & 96.2 & 0.190 & 0.442 & $0.127-1.543$ \\
\hline Inhibitory & 3DL2 & 110 & 100.0 & 105 & 100.0 & 1.000 & - & - \\
\hline Inhibitory & 3DL3 & 110 & 100.0 & 105 & 100.0 & 1.000 & - & - \\
\hline Activating & 3DS1 & 42 & 38.2 & 35 & 33.3 & 0.470 & 1.238 & $0.694-2.210$ \\
\hline Pseudogene & 2DP1 & 109 & 99.1 & 105 & 100.0 & 1.000 & 0.991 & $0.973-1.010$ \\
\hline Activating & 2DS4.FUL & 81 & 73.6 & 80 & 76.2 & 0.672 & 0.871 & $0.459-1.651$ \\
\hline Activating & 2DS4.DEL & 56 & 50.9 & 47 & 44.8 & 0.388 & 1.277 & $0.733-2.227$ \\
\hline Pseudogene & 3DP1.FUL & 15 & 13.6 & 8 & 7.6 & 0.168 & 1.914 & $0.751-4.874$ \\
\hline Pseudogene & 3DP1.DEL & 109 & 99.1 & 105 & 100.0 & 1.000 & 0.991 & $0.973-1.010$ \\
\hline
\end{tabular}

RSA, recurrent spontaneous abortion; KIR, killer cell immunoglobulin-like receptor.

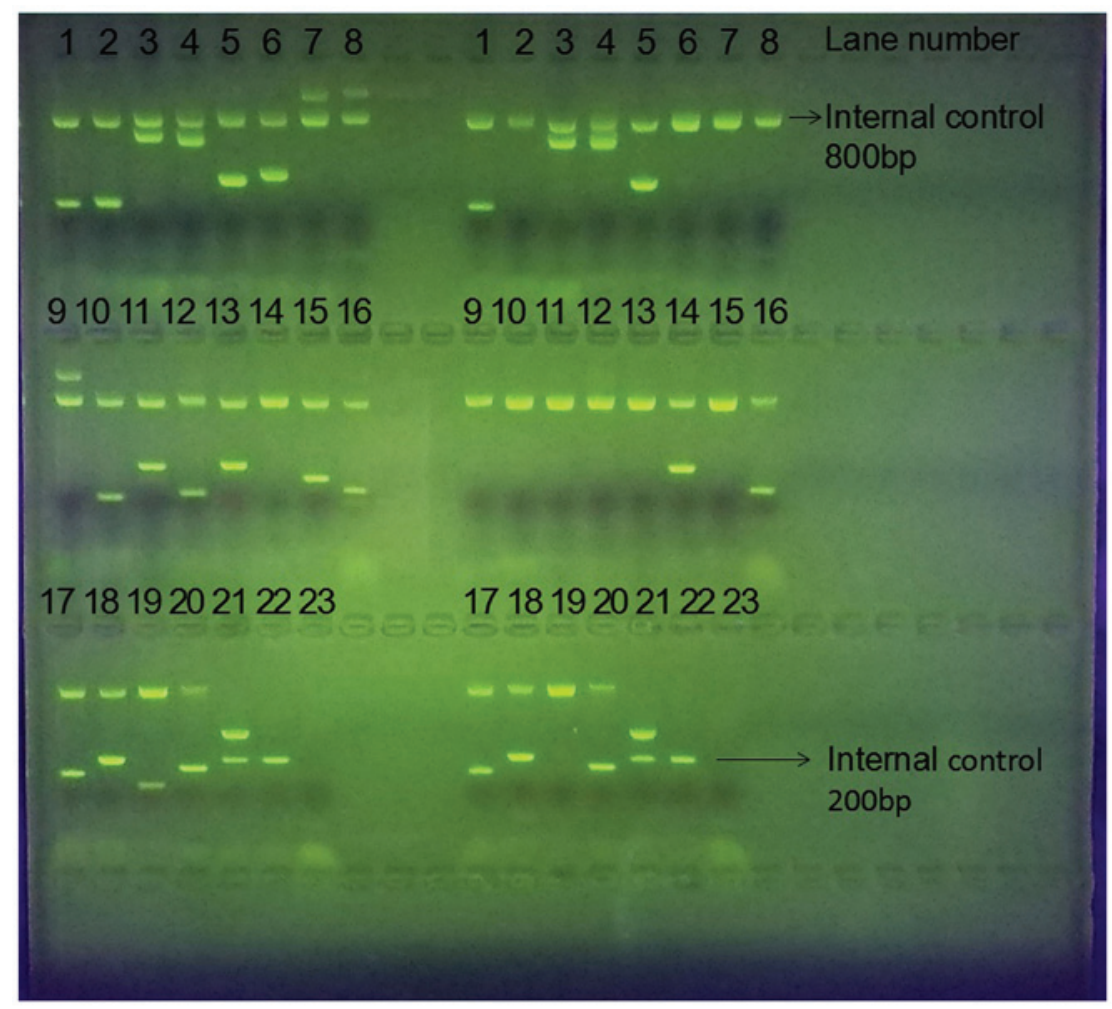

Figure 1. Representative agarose gel electrophoresis results. The DNA of two participants was separated by agarose gel electrophoresis to reveal their KIR genes. Each individual occupies 23 lanes consisting of 22 experiment lanes and one blank control lane (some genes were assigned duplicate lanes). In each experiment lane, there is an internal control polymerase chain reaction fragment (800 bp in lanes 1-20 and 200 bp in lanes 21-22). The bright bands in the experiment lanes correspond to the KIR genes. The two individuals' positive KIR genes are 2DL1, 2DL3, 2DL4, 2DS4FUL, 3DL1, 3DL2, 3DL3, 2DP1, 3DP1DEL (on the left) and 2DL1, 2DL3, 2DL4, 2DS4FUL, 2DS4DEL, 3DL1, 3DL2, 3DL3, 2DP1, 3DP1DEL (on the right). KIR, killer cell immunoglobulin-like receptors; bp, base pairs. 
Table II. Comparison of the frequency of KIR alleles in women who had miscarriage $\geq 3$ times ( $\mathrm{n}=40$ ) and the control group $(n=105)$.

\begin{tabular}{|c|c|c|c|c|c|c|c|c|}
\hline & & \multicolumn{2}{|c|}{ Patients } & \multicolumn{2}{|c|}{ Control group } & \multirow[b]{2}{*}{ P-value } & \multirow[b]{2}{*}{ Odds ratio } & \multirow[b]{2}{*}{$95 \%$ confidence interval } \\
\hline \multicolumn{2}{|c|}{ KIR genes } & $\mathrm{n}$ & $\%$ & $\mathrm{n}$ & $\%$ & & & \\
\hline Inhibitory & 2DL1 & 39 & 97.5 & 105 & 100.0 & 0.340 & 0.975 & $0.945-1.006$ \\
\hline Inhibitory & 2DL2 & 6 & 15.0 & 17 & 16.2 & 0.815 & 0.913 & $0.425-1.960$ \\
\hline Inhibitory & 2DL3 & 39 & 97.5 & 105 & 100.0 & 0.340 & 0.975 & $0.945-1.006$ \\
\hline Inhibitory & 2DL4 & 40 & 100.0 & 105 & 100.0 & 1.000 & - & - \\
\hline Inhibitory & 2DL5A & 14 & 35.0 & 37 & 35.2 & 0.976 & 0.991 & $0.555-1.772$ \\
\hline Inhibitory & 2DL5B & 2 & 5.0 & 10 & 9.5 & 0.220 & 0.501 & $0.164-1.537$ \\
\hline Activating & 2DS1 & 15 & 37.5 & 40 & 38.1 & 0.930 & 0.975 & $0.550-1.727$ \\
\hline Activating & 2DS2 & 6 & 15.0 & 17 & 16.2 & 0.815 & 0.913 & $0.425-1.960$ \\
\hline Activating & $2 \mathrm{DS} 3$ & 8 & 20.0 & 23 & 21.9 & 0.741 & 0.892 & $0.451-1.763$ \\
\hline Activating & 2DS5 & 12 & 30.0 & 23 & 21.9 & 0.191 & 1.528 & 0.807-2.894 \\
\hline Inhibitory & 3DL1 & 35 & 87.5 & 101 & 96.2 & $0.025^{a}$ & 0.277 & $0.085-0.904$ \\
\hline Inhibitory & 3DL2 & 40 & 100.0 & 105 & 100.0 & 1.000 & - & - \\
\hline Inhibitory & 3DL3 & 40 & 100.0 & 105 & 100.0 & 1.000 & - & - \\
\hline Activating & $3 \mathrm{DS} 1$ & 14 & 35.0 & 35 & 33.3 & 0.800 & 1.079 & $0.601-1.935$ \\
\hline Pseudogene & 2DP1 & 39 & 97.5 & 105 & 100.0 & 0.340 & 0.975 & $0.945-1.006$ \\
\hline Activating & 2DS4.FUL & 28 & 70.0 & 80 & 76.2 & 0.323 & 0.729 & $0.389-1.366$ \\
\hline Activating & 2DS4.DEL & 17 & 42.5 & 47 & 44.8 & 0.743 & 0.911 & $0.521-1.593$ \\
\hline Pseudogene & 3DP1.FUL & 5 & 12.5 & 8 & 7.6 & 0.249 & 1.737 & $0.673-4.481$ \\
\hline Pseudogene & 3DP1.DEL & 39 & 97.5 & 105 & 100.0 & 0.340 & 0.975 & $0.945-1.006$ \\
\hline
\end{tabular}

${ }^{\mathrm{a}} \mathrm{P}<0.05$ patient group vs. the control group. RSA, recurrent spontaneous abortion; KIR, killer cell immunoglobulin-like receptor.

KIR genotypes. The KIR genotypes were classified into three groups (AA, AB and $\mathrm{BB}$ ) in accordance with the following rules: i) The four framework genes KIR2DL4, 3DL2, 3DL3 and 3DP1 were present in all haplotypes; ii) the A haplotype contained at least six loci encoding inhibitory receptors (KIR3DL3, 2DL3, 2DL1, 3DP1, 2DL4, 3DL1 and 3DL2) and only one activating receptor (KIR2DS4) (40); and iii) if activating receptors characteristic of the $\mathrm{B}$ haplotypes were detected, the participants were designated as having either an $\mathrm{AB}$ genotype or a $\mathrm{BB}$ genotype.

In the present study, the RSA group was revealed as having 19 different genotypes, whereas the control group only had 17 (Fig. 2). The frequency of KIR genotypes was similar in the RSA and control group. The most frequent genotype identified in all participants $50.9 \%$ of the RSA group and $53.3 \%$ of the control group) consisted of the 3DL1, 2DL1, 2DL3, 2DS4, 2DL4, 3DL2, 3DL3, 2DP1 and 3DP1 genes, which corresponds with an AA genotype (genotype ID 1; Table III). The KIR AB genotypes accounted for 40.0 and $42.9 \%$ of patients in the RSA and control groups, respectively. The frequency of KIR BB genotypes was revealed as $9.1 \%$ of patients in the RSA group, compared with $3.8 \%$ of patients in the control group ( $\mathrm{P}=0.127$; OR, 2.534; CI, 0.740-8.679). The haplotypes may also be subdivided into centromeric and telomeric contents: Cen-A (2DL3 and 2DL1), Tel-A (3DL1 and 2DS4), Cen-B (2DS2, 2DL2, 2DL5B and 2DS3) and Tel-B (3DS1, 2DL5A, 2DS5 and 2DS1). Comparing the control group with the RSA group, no significant differences were identified between the centromeric and telomeric classifications exhibited.

When the women who had miscarried $\geq 3$ times were compared with the control group, the rate of the $\mathrm{BB}$ haplotype was significantly higher $(\mathrm{P}=0.025$; OR, 3.617; CI, 1.107-11.818; Table IV). Additionally, the frequency of the Tel-BB haplotype was also significantly higher in the women who have aborted $\geq 3$ times compared with the control group $(\mathrm{P}=0.025$; OR, 3.617; CI, 1.107-11.818).

Frequency of HLA-C alleles in RSA patients and controls. The frequencies of the HLA-C alleles $\mathrm{C} 1$ and $\mathrm{C} 2$, in the RSA and control groups were analyzed. No significant differences were identified between the two groups (Tables V and VI). The present study also analyzed the distribution of the HLA-C genotypes of KIR AA, AB and BB in the 2 groups (Tables $\mathrm{V}$ and VI). The frequency of HLA-C2C2 in KIR AB and KIR BB was significantly higher in the RSA group compared with the control group $(\mathrm{P}=0.024$ for KIR AB; $\mathrm{P}<0.001$ for KIR BB; Table $\mathrm{V}$ and $\mathrm{P}=0.014$ for KIR AB; $\mathrm{P}<0.001$ for KIR BB; Table VI). The co-existing frequency of KIR2DS1-C2 genes in the RSA group was slightly higher than in the control group, however it was not statistically different (20.9 vs. $18.1 \%, \mathrm{P}=0.617)$. The patients in the RSA group who had a homozygous HLA-C2C2 had a significantly higher frequency of the 2DS1 gene compared with the control group (45.5 vs. $0.0 \%$, respectively; $\mathrm{P}<0.001$; Fig. 3). 
Table III. Frequency of the KIR genotypes carriers in the RSA $(n=110)$ and the control $(n=105)$ groups.

\begin{tabular}{|c|c|c|c|c|c|c|c|}
\hline \multirow[b]{2}{*}{ KIR genotype } & \multicolumn{2}{|c|}{ RSA group } & \multicolumn{2}{|c|}{ Control group } & \multirow[b]{2}{*}{ P-value } & \multirow[b]{2}{*}{ Odds ratio } & \multirow[b]{2}{*}{$95 \%$ confidence interval } \\
\hline & $\mathrm{n}$ & $\%$ & $\mathrm{n}$ & $\%$ & & & \\
\hline \multicolumn{8}{|l|}{ KIR } \\
\hline AA & 56 & 50.9 & 56 & 53.3 & 0.734 & 0.908 & $0.521-1.582$ \\
\hline $\mathrm{AB}$ & 44 & 40.0 & 45 & 42.9 & 0.677 & 0.887 & $0.505-1.558$ \\
\hline $\mathrm{BB}$ & 10 & 9.1 & 4 & 3.8 & 0.127 & 2.534 & $0.740-8.679$ \\
\hline \multicolumn{8}{|l|}{ Cen } \\
\hline AA & 71 & 64.5 & 74 & 70.5 & 0.365 & 0.760 & $0.420-1.377$ \\
\hline $\mathrm{AB}$ & 37 & 33.6 & 31 & 29.5 & 0.533 & 1.209 & $0.665-2.198$ \\
\hline BB & 2 & 1.8 & 0 & 0.0 & 0.497 & 0.982 & 0.956-1.008 \\
\hline \multicolumn{8}{|l|}{ Tel } \\
\hline AA & 65 & 59.1 & 62 & 59.0 & 0.989 & 1.004 & $0.571-1.764$ \\
\hline $\mathrm{AB}$ & 36 & 32.7 & 39 & 37.1 & 0.514 & 0.824 & $0.460-1.475$ \\
\hline BB & 9 & 8.2 & 4 & 3.8 & 0.190 & 2.261 & $0.648-7.889$ \\
\hline
\end{tabular}

RSA, recurrent spontaneous abortion; KIR, killer cell immunoglobulin-like receptor; Cen, centromeric; Tel, telomeric.

\begin{tabular}{|c|c|c|c|c|c|c|c|c|c|c|c|c|c|c|c|c|c|c|c|}
\hline 3DL1 & 2DL1 & 2DL3 & 2DS4 & 2DL2 & 2DL5 & 3DS1 & 2DS1 & 2DS2 & $2 \mathrm{DS} 3$ & 2DS5 & 2DL4 & 3DL2 & 3DL3 & 2DP1 & 3DP1 & $\begin{array}{l}\text { Hapl } \\
\text { Group }\end{array}$ & $\begin{array}{c}\text { Genotype } \\
\text { ID }\end{array}$ & $\begin{array}{c}\text { Number of } \\
\text { individuals } \\
\text { in RSA } \\
\text { group }\end{array}$ & $\begin{array}{c}\text { Number of } \\
\text { individuals } \\
\text { in control } \\
\text { group }\end{array}$ \\
\hline & & & & & & & & & & & & & & & & AA & 1 & 56 & 56 \\
\hline & & & & & & & & & & & & & & & & $\mathrm{AB}$ & 2 & 13 & 14 \\
\hline & & & & & & & & & & & & & & & & $\mathrm{AB}$ & 8 & 8 & 12 \\
\hline & & & & & & & & & & & & & & & & $\mathrm{AB}$ & 4 & 6 & 4 \\
\hline & & & & & & & & & & & & & & & & $\mathrm{AB}$ & 3 & 3 & 1 \\
\hline & & & & & & & & & & & & & & & & $\mathrm{AB}$ & 6 & 3 & 2 \\
\hline & & & & & & & & & & & & & & & & BB & 75 & 3 & 1 \\
\hline & & & & & & & & & & & & & & & & $\mathrm{AB}$ & 28 & 3 & 0 \\
\hline & & & & & & & & & & & & & & & & $\mathrm{AB}$ & 9 & 2 & 1 \\
\hline & & & & & & & & & & & & & & & & BB & 69 & 2 & 1 \\
\hline & & & & & & & & & & & & & & & & BB & 117 & 2 & 0 \\
\hline & & & & & & & & & & & & & & & & $A B$ & 260 & 2 & 0 \\
\hline & & & & & & & & & & & & & & & & $\mathrm{AB}$ & 5 & 1 & 2 \\
\hline & & & & & & & & & & & & & & & & $\mathrm{AB}$ & 11 & 1 & 3 \\
\hline & & & & & & & & & & & & & & & & $\mathrm{AB}$ & 13 & 1 & 0 \\
\hline & & & & & & & & & & & & & & & & $\mathrm{AB}$ & 18 & 1 & 0 \\
\hline & & & & & & & & & & & & & & & & BB & 74 & 1 & 0 \\
\hline & & & & & & & & & & & & & & & & BB & 90 & 1 & 0 \\
\hline & & & & & & & & & & & & & & & & BB & 159 & 1 & 0 \\
\hline & & & & & & & & & & & & & & & & $A B$ & 7 & 0 & 2 \\
\hline & & & & & & & & & & & & & & & & $\mathrm{AB}$ & 200 & 0 & 2 \\
\hline & & & & & & & & & & & & & & & & $\mathrm{AB}$ & 15 & 0 & 1 \\
\hline & & & & & & & & & & & & & & & & $\mathrm{AB}$ & 23 & 0 & 1 \\
\hline & & & & & & & & & & & & & & & & BB & 68 & 0 & 1 \\
\hline & & & & & & & & & & & & & & & & BB & 70 & 0 & 1 \\
\hline
\end{tabular}

Figure 2. Distribution of KIR genotypes in the RSA and control group. A total of 16 KIR genes were used to distinguish KIR A and B haplotypes. The gray boxes represent the presence of the KIR gene and the white boxes represent their absence. A total of 19 and 17 KIR genotypes were identified in the RSA and control groups, respectively. KIR, killer cell immunoglobulin-like receptor; RSA, recurrent spontaneous abortion.

\section{Discussion}

During a normal pregnancy, a fetus grows in the maternal womb for nearly 40 weeks as an allogeneic entity without causing immune rejection. Immune dysfunction at the maternal-fetal interface may be associated with RSA (41). Previous studies have revealed that uNKs serve an important role in regulating the invasion of trophoblastic cells $(13,14)$. During pregnancy a large number of uNKs converge in the maternal decidua and express KIRs (8). Meanwhile, the placental villous trophoblastic cells express HLA-C, -E, and $-\mathrm{G}$ molecules, which predominantly combine with uNK receptors (42-44). As fetal trophoblast cells make direct contact with the uterine tissues, appropriate recognition and immune responses in the maternal-fetal interface are essential for fetal growth and to prevent excessive placenta invasion or allogeneic rejection (4). Human uNKs secrete abundant cytokines and angiogenic growth factors, which serve a prominent 
Table IV. Frequency of KIR genotypes carriers in women who had miscarriage $\geq 3$ times $(\mathrm{n}=40)$ and the control group ( $\mathrm{n}=105)$.

\begin{tabular}{|c|c|c|c|c|c|c|c|}
\hline \multirow[b]{2}{*}{ KIR genotype } & \multicolumn{2}{|c|}{$\begin{array}{c}\text { RSA group } \\
\text { with } \geq 3 \\
\text { miscarriages }\end{array}$} & \multicolumn{2}{|c|}{ Controls } & \multirow[b]{2}{*}{ P-value } & \multirow[b]{2}{*}{ Odds ratio } & \multirow[b]{2}{*}{$95 \%$ confidence interval } \\
\hline & $\mathrm{n}$ & $\%$ & $\mathrm{n}$ & $\%$ & & & \\
\hline \multicolumn{8}{|l|}{ KIR } \\
\hline $\mathrm{AA}$ & 22 & 55.0 & 56 & 53.3 & 0.809 & 1.071 & $0.614-1.868$ \\
\hline $\mathrm{AB}$ & 13 & 32.5 & 45 & 42.9 & 0.129 & 0.641 & $0.360-1.140$ \\
\hline $\mathrm{BB}$ & 5 & 12.5 & 4 & 3.8 & $0.025^{\mathrm{a}}$ & 3.617 & $1.107-11.818$ \\
\hline \multicolumn{8}{|l|}{ Cen } \\
\hline AA & 27 & 67.5 & 74 & 70.5 & 0.646 & 0.869 & $0.477-1.583$ \\
\hline $\mathrm{AB}$ & 12 & 30.0 & 31 & 29.5 & 0.938 & 1.024 & $0.559-1.878$ \\
\hline $\mathrm{BB}$ & 1 & 2.5 & 0 & 0.0 & 0.246 & 0.975 & $0.945-1.006$ \\
\hline \multicolumn{8}{|l|}{ Tel } \\
\hline $\mathrm{AA}$ & 25 & 62.5 & 62 & 59.0 & 0.612 & 1.158 & $0.656-2.044$ \\
\hline $\mathrm{AB}$ & 10 & 25.0 & 39 & 37.1 & 0.064 & 0.565 & $0.308-1.038$ \\
\hline BB & 5 & 12.5 & 4 & 3.8 & $0.025^{\mathrm{a}}$ & 3.617 & $1.107-11.818$ \\
\hline
\end{tabular}

${ }^{a} \mathrm{P}<0.05$ patient group vs. the control group $(\mathrm{P}=0.025)$. RSA, recurrent spontaneous abortion; KIR, killer cell immunoglobulin-like receptor; Cen, centromeric; Tel, telomeric.

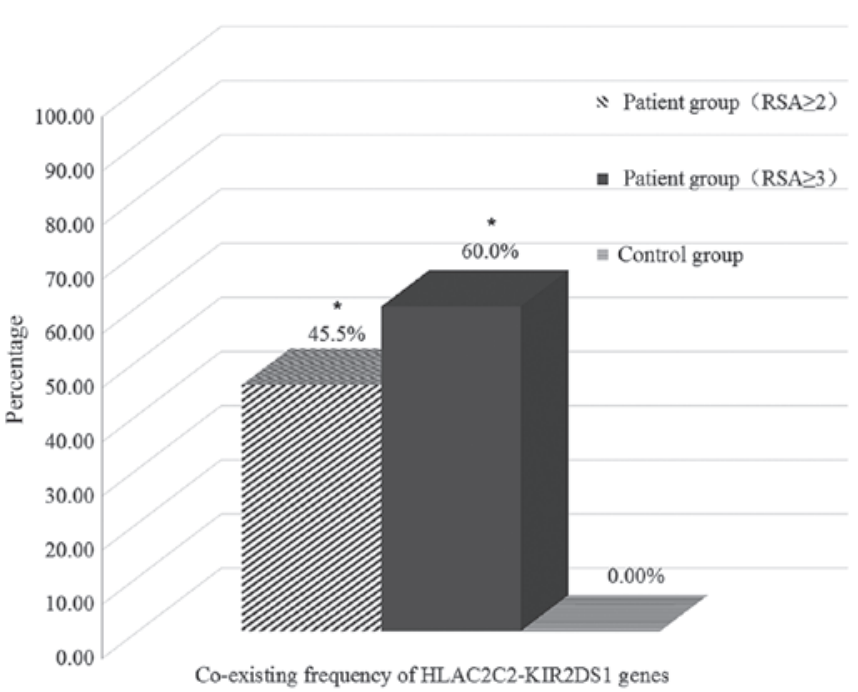

Figure 3. Co-existing frequency of C2C2-KIR2DS1 genes in the RSA and control groups. The women in the RSA group who had a homozygous HLA-C2C2 had a significantly higher frequency of the 2DS1 gene compared with the control group. In women who had aborted $\geq 3$ times this frequency increased to $60 \%$. ${ }^{*} \mathrm{P}<0.001$ vs. the control group. RSA, recurrent spontaneous abortion; KIR, killer cell immunoglobulin-like receptor; HLA, human leukocyte antigen.

role in trophoblast cell invasion and placentation $(13,14)$. Changes to the number or function of uNKs may lead to the development of an abnormal uterine local environment, which makes it difficult for the fetus to survive (45). Several previous studies have demonstrated that certain deleterious HLA-KIR pairings affect the secretion of cytokines and the expression of receptors, which may result in a range of pregnancy complications, including pre-eclampsia, fetal growth restriction and RSA $(27,31,46)$.
A recent study demonstrated that significant differences exist in the frequency of KIR3DL1, 2DS4, 2DS1 and 2DS5 genes in 10 Han Chinese populations form different regions in China (47). This suggests that investigators who have considered the differences between ethnic groups, but have not considered the differences in geographical regions, may form mistaken conclusions when analyzing the correlations between KIR and disease. In the present study, the variation of KIRs in different ethnic and geographical groups was fully considered and all participants recruited to the study were from the same area and of the same ethnicity with no other regional migration known for three generations. The KIR and HLA-C genes present in the Han Chinese normal women and patients with RSA were detected, and it was investigated whether certain genotypes were more susceptible to RSA. To the best of our knowledge, the present study is the first time an association has been demonstrated between the UNK KIR and HLA-C genes in women of Han Chinese ethnicity with RSA. As it was not possible to collect all of the aborted fetuses from patients with RSA, there is a possibility that chromosomal aneuploidy in the fetus may have led to miscarriage, although this is unlikely to have been the cause in all cases. A previous study evaluated the karyotypes of the products of conception in women with RSA and revealed the frequency of abnormal chromosomes did not differ from the whole population (48).

The mechanism by which NK cells develop a tolerance to normal self-tissues depends mainly on the 'missing self' mechanism (49). In a normal situation, inhibitory KIRs interact with specific cognate HLA ligands that generate inhibitory signals and thereby prevent NK cells from being activated (50). The interactions of activation receptors with their self-specific ligands may result in NK cells hyporesponsiveness or reduced expression of cognate receptors (51). A previous study revealed that many NK cells with anti-HLA-C2 reactivity were present 
Table V. Comparison of the frequency of HLA-C genotypes in the RSA $(n=110)$ and control $(n=105)$ groups.

\begin{tabular}{|c|c|c|c|c|c|c|}
\hline \multirow[b]{2}{*}{ KIR genotype } & \multirow{2}{*}{$\begin{array}{l}\text { HLA-C } \\
\text { genotype }\end{array}$} & \multicolumn{2}{|c|}{ RSA group } & \multicolumn{2}{|c|}{ Control group } & \multirow[b]{2}{*}{ P-value } \\
\hline & & $\mathrm{n}$ & $\%$ & $\mathrm{n}$ & $\%$ & \\
\hline \multirow{6}{*}{$\begin{array}{l}\text { Total no. of } \\
\text { genotype carriers } \\
\text { in each group } \\
\text { KIRAA }\end{array}$} & $\mathrm{C} 1 \mathrm{C} 1$ & 53 & 48.2 & 48 & 45.7 & 0.723 \\
\hline & $\mathrm{C} 1 \mathrm{C} 2$ & 46 & 41.8 & 50 & 47.6 & 0.409 \\
\hline & $\mathrm{C} 2 \mathrm{C} 2$ & 11 & 10.0 & 7 & 6.7 & 0.399 \\
\hline & $\mathrm{C} 1 \mathrm{C} 1$ & 25 & 44.6 & 21 & 37.5 & 0.307 \\
\hline & $\mathrm{C} 1 \mathrm{C} 2$ & 25 & 44.6 & 28 & 50.0 & 0.444 \\
\hline & $\mathrm{C} 2 \mathrm{C} 2$ & 6 & 10.7 & 7 & 12.5 & 0.691 \\
\hline \multirow[t]{3}{*}{ KIRAB } & $\mathrm{C} 1 \mathrm{C} 1$ & 24 & 54.5 & 25 & 55.6 & 0.876 \\
\hline & $\mathrm{C} 1 \mathrm{C} 2$ & 17 & 38.6 & 20 & 44.4 & 0.405 \\
\hline & $\mathrm{C} 2 \mathrm{C} 2$ & 3 & 6.8 & 0 & 0.0 & $0.024^{\mathrm{a}}$ \\
\hline \multirow[t]{3}{*}{ KIRBB } & $\mathrm{C} 1 \mathrm{C} 1$ & 4 & 40.0 & 2 & 50.0 & 0.155 \\
\hline & $\mathrm{C} 1 \mathrm{C} 2$ & 4 & 40.0 & 2 & 50.0 & 0.155 \\
\hline & $\mathrm{C} 2 \mathrm{C} 2$ & 2 & 20.0 & 0 & 0.0 & $<0.001^{\mathrm{a}}$ \\
\hline
\end{tabular}

${ }^{\mathrm{a}} \mathrm{P}<0.05$ patient group vs. the control group. Pearson Chi-square continuity correction was performed. RSA, recurrent spontaneous abortion; KIR, killer cell immunoglobulin-like receptor; HLA-C, human leukocyte antigen-C.

Table VI. Comparison of the frequency of HLA-C genotypes in women who miscarried $\geq 3$ times $(n=40)$ and the control group $(\mathrm{n}=105)$.

\begin{tabular}{|c|c|c|c|c|c|c|}
\hline \multirow[b]{2}{*}{ KIR genotype } & \multirow[b]{2}{*}{ HLA-C genotype } & \multicolumn{2}{|c|}{$\begin{array}{l}\text { RSA group with } \\
\geq 3 \text { miscarriages }\end{array}$} & \multicolumn{2}{|c|}{ Controls } & \multirow[b]{2}{*}{ P-value } \\
\hline & & $\mathrm{n}$ & $\%$ & $\mathrm{~N}$ & $\%$ & \\
\hline \multirow{3}{*}{$\begin{array}{l}\text { Total no. of } \\
\text { genotype } \\
\text { carriers in } \\
\text { each group }\end{array}$} & $\mathrm{C} 1 \mathrm{C} 1$ & 19 & 47.5 & 48 & 45.7 & 0.799 \\
\hline & $\mathrm{C} 1 \mathrm{C} 2$ & 16 & 40.0 & 50 & 47.6 & 0.279 \\
\hline & $\mathrm{C} 2 \mathrm{C} 2$ & 5 & 12.5 & 7 & 6.7 & 0.164 \\
\hline \multirow[t]{3}{*}{ KIRAA } & $\mathrm{C} 1 \mathrm{C} 1$ & 9 & 40.9 & 21 & 37.5 & 0.622 \\
\hline & $\mathrm{C} 1 \mathrm{C} 2$ & 11 & 50.0 & 28 & 50.0 & 1.000 \\
\hline & $\mathrm{C} 2 \mathrm{C} 2$ & 2 & 9.1 & 7 & 12.5 & 0.439 \\
\hline \multirow[t]{3}{*}{ KIRAB } & $\mathrm{C} 1 \mathrm{C} 1$ & 8 & 61.5 & 25 & 55.6 & 0.397 \\
\hline & $\mathrm{C} 1 \mathrm{C} 2$ & 4 & 30.8 & 20 & 44.4 & $0.047^{\mathrm{a}}$ \\
\hline & $\mathrm{C} 2 \mathrm{C} 2$ & 1 & 7.7 & 0 & 0.0 & $0.014^{\mathrm{a}}$ \\
\hline \multirow[t]{3}{*}{ KIRBB } & $\mathrm{C} 1 \mathrm{C} 1$ & 2 & 40.0 & 2 & 50.0 & 0.155 \\
\hline & $\mathrm{C} 1 \mathrm{C} 2$ & 1 & 20.0 & 2 & 50.0 & $<0.001^{\mathrm{a}}$ \\
\hline & $\mathrm{C} 2 \mathrm{C} 2$ & 2 & 40.0 & 0 & 0.0 & $<0.001^{\mathrm{a}}$ \\
\hline
\end{tabular}

${ }^{\mathrm{a}} \mathrm{P}<0.05$ patient group vs. the control group. Pearson Chi-square continuity correction was performed. RSA, recurrent spontaneous abortion; KIR, killer cell immunoglobulin-like receptor; HLA-C, human leukocyte antigen-C.

in HLA-C1 homozygous and heterozygous healthy individuals with 2DS1, but not in HLA-C2 homozygous donors (52). This suggests that the functions of NK cells in vivo are critically regulated. A self-stabilization mechanism may exist in NK cells, allowing them to maintain homeostasis by self-regulating, however, when interference forces are above the self-regulation ability, referred to as the 'threshold effect', an immune attack will be activated and external factors are required to restore homeostasis (53).
In the present study, it was demonstrated that the KIR AA haplotype frequency of the two groups was similar, which was in line with the results reported by other studies in Han Chinese populations $(54,55)$. No statistical significances were identified in the frequency of KIR genes in the RSA group compared with the control group. No significant difference was identified in the frequency of HLA-C alleles between the patients with RSA and the controls. A similar conclusion was reached by Christiansen et al (56). In the present study, the frequency 
of the KIR3DL1 gene was significantly reduced in women who had aborted $\geq 3$ times $(n=40)$ compared with the control $(n=105)$. The inhibitory KIR3DL1 gene is one of the most polymorphic KIR genes (57). The ligand for the KIR3DL1 receptor is the Bw4 epitope present on several HLA-B molecules, which is not expressed by fetal trophoblast cells (58). In patients with pulmonary artery hypertension, the expression of 3DL1 is lower and its function is disrupted, suggesting a central role for KIRs in the occurrence and development of immune-associated vascular diseases (59). The decreased frequency of the KIR3DL1 gene in patients who have miscarried $\geq 3$ times may lead to the weakened inhibition of NK cells, which contributes to the imbalance of steady state and works against fetal survival. The different significance results that were identified between women who had miscarried $\geq 3$ times and those who had not, suggests that this should be considered as a selection criteria when miscarriage diseases are being researched. A previous study also demonstrated that there was a decreased expression frequency of the UNK KIR2DL1 receptor in women with RSA who carried a C2 epitope (10). In the present study, the high rate of HLA-C2C2 in KIR AB and KIR BB individuals may decrease the expression of the KIR2DL1 receptor and simultaneously generate strong activation effects, which breaks the self-adjustment ability of NKs and activates NK-mediated immunological rejection of the fetus.

Komlos et al (60) first demonstrated that couples sharing common HLA antigens had a significantly higher percentage of repeated miscarriages compared with the control group. This led to further research on the subject and certain studies identified that KIRs were associated with RSA, however, there are disagreements over the underlying mechanisms. Varla-Leftherioti et al (61) revealed there was a lower frequency of inhibitory KIRs (inhibitory 2DL1, 2 and 3) in the peripheral blood and decidual tissue of women suffering multiple miscarriages, compared with fertile females. Other studies identified inhibitory genotypes as more common in the control subjects and activating genotypes as more common in patients with RSA $(29,30,46,62)$. The frequency of the KIR2DS1 gene has been demonstrated to be significantly higher in patients with RSA compared with healthy controls (63). However, the frequency of activating KIR genes demonstrated no significant differences between the two groups in the present study. The KIR2DS1 gene combined with a specific ligand may generate a strong activation effect in NKs (64). The activation of KIR2DS1+uNKs, stimulated by fetal HLA-C2, may form soluble products, including granulocyte-macrophage colony-stimulating factor, which enhances the migration of primary trophoblast cells (65). A recent study also indicated that the co-expression of KIR2DS1 and HLA-C2 may be associated with RSA (66). In the present study, the co-existing frequency of KIR2DS1-C2 genes in patients with RSA was slightly higher than in the control groups (20.9 vs. 18.1\%). However, the women in the RSA group who had a homozygous HLA-C2C2 had a significantly higher frequency of the 2DS1 gene compared with the control group (45.5 vs $0.0 \%$; $\mathrm{P}<0.001)$. Furthermore, in women who had aborted $\geq 3$ times this frequency was at $60.0 \%$. This supports the hypothesis that strong activation effects surpass the self-regulation of NKs and alter their secretory activity into cell toxicity, which may ultimately lead to spontaneous miscarriage.
Previous research reported that the frequency of the KIR BB genotype was significantly lower and the KIR AB genotype was significantly higher in the RSA group compared with the control cohort (29). Additionally, infertile patients who carry the KIR A haplotype experienced fewer pregnancy losses following euploid single-embryo transfer compared with KIR B haplotype carriers (28). In the Han Chinese population, the KIR AA genotype has a high prevalence, which may reach up to half of the total number of the population in some areas (47), however, no difference was identified in the frequency of the KIR AA genotype between the two groups in the present study. The rate of the BB genotype was significantly higher in women who had aborted $\geq 3$ times compared with the control group. Alternatively, certain previous studies have suggested that the maternal AA genotype is associated with an increased risk of pregnancy complications and the activation of uNK cells is a generic mechanism promoting trophoblast invasion into the decidua $(27,31,32,46,67)$. The 2DL1 gene in all AA individuals represents the highest inhibitory influence when interacting with HLA-C2, which is characterized by a lack of appropriate cytokines to enforce uterine arterial remodeling, thus leading to poor placentation and ultimately fetal loss $(32,46,58,68)$. In the present study, these tendencies were not identified.

In summary, many viewpoints have been published on how RSA is associated with individual genetics, but the underlying molecular basis of the disease has not yet been determined. To date, a variety of therapeutic regimens have been used in the clinical treatment of RSA, with varying results $(6,69,70)$. Meta-analyses have concluded that paternal cell immunization, third-party donor leukocytes, trophoblast membranes and intravenous immunoglobulin trials did not improve the live birth rate or have a beneficial effect in women with previous unexplained recurrent miscarriage (69,71-73). A full understanding of the underlying pathogenesis of RSA is required prior to the development of an effective treatment plan, which may assist patients in completing successful pregnancies. The results of the present study revealed that in patients with RSA (miscarried $\geq 3$ times), the frequency of inhibitory genes was reduced while activated gene combinations increased when compared with the control group. The self-activation of the maternal NK cells or the reduction of the activation threshold may result in NK cells becoming susceptible to irritability, which may be associated with the occurrence of RSA. The experimental results provide an insight for further study on miscarriage induced by maternal-fetal interface immune disorders. In addition, the results may have clinical therapeutic significance, helping select suitable fertilized eggs for women who are at high risk of recurrent spontaneous abortion and reduce the activation of $\mathrm{uNKs}$ and the incidence of pregnancy complications. Comprehensive analysis of large groups is required to obtain useful results. This is dependent on concerted efforts from multiple regions due to the varied nature of KIR genes throughout different ethnicities and locations.

\section{Acknowledgements}

The present study was supported by the National Natural Science Foundation of China (grant nos. 81501336 and 81450018). 


\section{References}

1. Stirrat GM: Recurrent miscarriage. Lancet 336: 673-675, 1990

2. Evaluation and treatment of recurrent pregnancy loss: A committee opinion. Fertil Steril 98: 1103-1111, 2012.

3. van den Boogaard E, Kaandorp SP, Franssen MT, Mol BW, Leschot NJ, Wouters CH, van der Veen F, Korevaar JC and Goddijn M: Consecutive or non-consecutive recurrent miscarriage: Is there any difference in carrier status?. Hum Reprod 25 $1411-1414,2010$

4. Moffett A and Loke C: Immunology of placentation in eutherian mammals. Nat Rev Immunol 6: 584-594, 2006.

5. Moffett-King A: Natural killer cells and pregnancy. Nat Rev Immunol 2: 656-663, 2002

6. Cavalcante MB, Sarno M, Araujo Junior E, Da Silva Costa F and Barini R: Lymphocyte immunotherapy in the treatment of recurrent miscarriage: Systematic review and meta-analysis. Arch Gynecol Obstet 295: 511-518, 2017.

7. Ravet S, Scott-Algara D, Bonnet E, Tran HK, Tran T, Nguyen N, Truong LX, Theodorou I, Barré-Sinoussi F, Pancino G and Paul P: Distinctive NK-cell receptor repertoires sustain high-level constitutive NK-cell activation in HIV-exposed uninfected individuals. Blood 109: 4296-4305, 2007.

8. Koopman LA, Kopcow HD, Rybalov B, Boyson JE, Orange JS Schatz F, Masch R, Lockwood CJ, Schachter AD, Park PJ and Strominger JL: Human decidual natural killer cells are a unique NK cell subset with immunomodulatory potential. J Exp Med 198: 1201-1212, 2003.

9. King A, Burrows T, Verma S, Hiby S and Loke YW: Human uterine lymphocytes. Hum Reprod Update 4: 480-485, 1998.

10. Sharkey AM, Xiong S, Kennedy PR, Gardner L, Farrell LE, Chazara O, Ivarsson MA, Hiby SE, Colucci F and Moffett A: Tissue-specific education of decidual NK cells. J Immunol 195: 3026-3032, 2015.

11. Shi FD, Ljunggren HG, La Cava A and Van Kaer L: Organ-specific features of natural killer cells. Nat Rev Immunol 11: 658-671, 2011.

12. Ferlazzo G, Tsang ML, Moretta L, Melioli G, Steinman RM and Münz C: Human dendritic cells activate resting natural killer (NK) cells and are recognized via the NKp30 receptor by activated NK cells. J Exp Med 195: 343-351, 2002.

13. Lash GE, Naruse K, Robson A, Innes BA, Searle RF, Robson SC and Bulmer JN: Interaction between uterine natural killer cells and extravillous trophoblast cells: Effect on cytokine and angiogenic growth factor production. Hum Reprod 26: 2289-2295, 2011.

14. van der Meer A, Lukassen HG, van Lierop MJ, Wijnands F, Mosselman S, Braat DD and Joosten I: Membrane-bound HLA-G activates proliferation and interferon-gamma production by uterine natural killer cells. Mol Hum Reprod 10: 189-195, 2004.

15. Raulet DH and Vance RE: Self-tolerance of natural killer cells. Nat Rev Immunol 6: 520-531, 2006.

16. Lanier LL: NK cell recognition. Annu Rev Immunol 23: 225-274, 2005.

17. Uhrberg M, Valiante NM, Shum BP, Shilling HG, LienertWeidenbach K, Corliss B, Tyan D, Lanier LL and Parham P: Human diversity in killer cell inhibitory receptor genes. Immunity 7 : 753-763, 1997.

18. Varla-Leftherioti M, Spyropoulou-Vlachou M, Niokou D, KeramitsoglouT,DarlamitsouA,TsekouraC,PapadimitropoulosM, Lepage V, Balafoutas C and Stavropoulos-Giokas C: Natural killer (NK) cell receptors' repertoire in couples with recurrent spontaneous abortions. Am J Reprod Immunol 49: 183-191, 2003.

19. Vivier E, Nunès JA and Vély F: Natural killer cell signaling pathways. Science 306: 1517-1519, 2004.

20. Yokoyama WM and Plougastel BF: Immune functions encoded by the natural killer gene complex. Nat Rev Immunol 3: 304-316, 2003.

21. Vilches C and Parham P: KIR: Diverse, rapidly evolving receptors of innate and adaptive immunity. Annu Rev Immunol 20: 217-251, 2002

22. Uhrberg M, Parham P and Wernet P: Definition of gene content for nine common group B haplotypes of the Caucasoid population: KIR haplotypes contain between seven and eleven KIR genes. Immunogenetics 54: 221-229, 2002.

23. Pyo CW, Guethlein LA, Vu Q, Wang R, Abi-Rached L, Norman PJ, Marsh SG, Miller JS, Parham P and Geraghty DE: Different patterns of evolution in the centromeric and telomeric regions of group A and B haplotypes of the human killer cell Ig-like receptor locus. PloS one 5: e15115, 2010.
24. Alter G, Heckerman D, Schneidewind A, Fadda L, Kadie CM, Carlson JM, Oniangue-Ndza C, Martin M, Li B, Khakoo SI, et al: HIV-1 adaptation to NK-cell-mediated immune pressure. Nature 476: 96-100, 2011.

25. de Smith AJ, Walsh KM, Ladner MB, Zhang S, Xiao C, Cohen F, Moore TB, Chokkalingam AP, Metayer C, Buffler PA, et al: The role of KIR genes and their cognate HLA class I ligands in childhood acute lymphoblastic leukemia. Blood 123: 2497-2503, 2014

26. Cooley S, Weisdorf DJ, Guethlein LA, Klein JP, Wang T, Marsh SG, Spellman S, Haagenson MD, Saeturn K, Ladner M, et al: Donor killer cell Ig-like receptor B haplotypes, recipient HLA-C1 and HLA-C mismatch enhance the clinical benefit of unrelated transplantation for acute myelogenous leukemia. J Immunol 192: 4592-4600, 2014.

27. Nakimuli A, Chazara O, Hiby SE, Farrell L, Tukwasibwe S, Jayaraman J, Traherne JA, Trowsdale J, Colucci F, Lougee E, et al: A KIR B centromeric region present in Africans but not Europeans protects pregnant women from pre-eclampsia. Proc Natl Acad Sci USA 112: 845-850, 2015.

28. Morin SJ, Treff NR, Tao X, Scott RT III, Franasiak JM, Juneau CR, Maguire M and Scott RT: Combination of uterine natural killer cell immunoglobulin receptor haplotype and trophoblastic HLA-C ligand influences the risk of pregnancy loss: A retrospective cohort analysis of direct embryo genotyping data from euploid transfers. Fertil Steril 107: 677-683, 2017.

29. Ozturk OG, Sahin G, Karacor ED and Kucukgoz U: Evaluation of KIR genes in recurrent miscarriage. J Assist Reprod Genet 29: 933-938, 2012

30. Vargas RG, Bompeixe EP, Franca PP, Marques de Moraes M and da Graca Bicalho M: Activating killer cell immunoglobulin-like receptor genes' association with recurrent miscarriage. Am J Reprod Immunol 62: 34-43, 2009.

31. Alecsandru D, Garrido N, Vicario JL, Barrio A, Aparicio P, Requena A and García-Velasco JA: Maternal KIR haplotype influences live birth rate after double embryo transfer in IVF cycles in patients with recurrent miscarriages and implantation failure. Hum Reprod 29: 2637-2643, 2014.

32. Hiby SE, Apps R, Sharkey AM, Farrell LE, Gardner L, Mulder A, Claas FH, Walker JJ, Redman CW, Morgan L, et al: Maternal activating KIRs protect against human reproductive failure mediated by fetal HLA-C2. J Clin Invest 120: 4102-4110, 2010.

33. Toneva M, Lepage V, Lafay G, Dulphy N, Busson M, Lester S, Vu-Trien A, Michaylova A, Naumova E, McCluskey J and Charron D: Genomic diversity of natural killer cell receptor genes in three populations. Tissue Antigens 57: 358-362, 2001.

34. Yao Y, Shi L, Tao Y, Lin K, Liu S, Yu L, Yang Z, Yi W, Huang X, Sun H, et al: Diversity of killer cell immunoglobulin-like receptor genes in four ethnic groups in China. Immunogenetics 63: 475-483, 2011

35. Liu H, Shan Z, Li C, Mao J, Xie X, Wang W, Fan C, Wang H, Zhang $\mathrm{H}$, Han $\mathrm{C}$, et al: Maternal subclinical hypothyroidism, thyroid autoimmunity, and the risk of miscarriage: A prospective cohort study. Thyroid 24: 1642-1649, 2014.

36. Kishore J, Agarwal J, Agrawal S and Ayyagari A: Seroanalysis of Chlamydia trachomatis and S-TORCH agents in women with recurrent spontaneous abortions. Indian J Pathol Microbiol 46: 684-687, 2003

37. Simcox LE, Ormesher L, Tower C and Greer IA: Thrombophilia and pregnancy complications. Int J Mol Sci 16: 28418-28428, 2015.

38. Tajik N, Shahsavar F, Nasiri M and Radjabzadeh MF: Compound KIR-HLA genotype analyses in the Iranian population by a novel PCR-SSP assay. Int J Immunogenet 37: 159-168, 2010.

39. Schaap T: The applicability of the Hardy-Weinberg principle in the study of populations. Ann Hum Genet 44: 211-215, 1980.

40. Martin AM, Freitas EM, Witt CS and Christiansen FT: The genomic organization and evolution of the natural killer immunoglobulin-like receptor (KIR) gene cluster. Immunogenetics 51: 268-280, 2000

41. Meuleman T, Cohen D, Swings GM, Veraar K, Claas FH and Bloemenkamp KW: Increased complement C4d deposition at the maternal-fetal interface in unexplained recurrent miscarriage. J Reprod Immunol 113: 54-60, 2016.

42. Dahl M and Hviid TV: Human leucocyte antigen class Ib molecules in pregnancy success and early pregnancy loss. Hum Reprod Update 18: 92-109, 2012.

43. King A, Allan DS, Bowen M, Powis SJ, Joseph S, Verma S, Hiby SE, McMichael AJ, Loke YW and Braud VM: HLA-E is expressed on trophoblast and interacts with CD94/NKG2 receptors on decidual NK cells. Eur J Immunol 30: 1623-1631, 2000. 
44. Apps R, Gardner L, Sharkey AM, Holmes N and Moffett A: A homodimeric complex of HLA-G on normal trophoblast cells modulates antigen-presenting cells via LILRB1. Eur J Immunol 37: 1924-1937, 2007.

45. Brosens I, Pijnenborg R, Vercruysse L and Romero R: The 'Great Obstetrical Syndromes' are associated with disorders of deep placentation. Am J Obstet Gynecol 204: 193-201, 2011.

46. Hiby SE, Walker JJ, O'Shaughnessy KM, Redman CW, Carrington M, Trowsdale $\mathrm{J}$ and Moffett A: Combinations of maternal KIR and fetal HLA-C genes influence the risk of preeclampsia and reproductive success. J Exp Med 200: 957-965, 2004.

47. Yin C, Hu L, Huang H, Yu Y, Li Z, Ji Q, Kong X, Wang Z, Yan J, Yan J, et al: Genetic polymorphism and evolutionary differentiation of Eastern Chinese Han: A comprehensive and comparative analysis on KIRs. Sci Rep 7: 42486, 2017.

48. Orlando J and Coulam C: Is superfertility associated with recurrent pregnancy loss? Am J Reprod Immunol 72: 549-554, 2014.

49. Raulet DH, Vance RE and McMahon CW: Regulation of the natural killer cell receptor repertoire. Annu Rev Immunol 19: 291-330, 2001

50. Emmer PM, Steegers EA, Kerstens HM, Bulten J, Nelen WL, Boer K and Joosten I: Altered phenotype of HLA-G expressing trophoblast and decidual natural killer cells in pathological pregnancies. Hum Reprod 17: 1072-1080, 2002.

51. Tripathy SK, Keyel PA, Yang L, Pingel JT, Cheng TP, Schneeberger A and Yokoyama WM: Continuous engagement of a self-specific activation receptor induces NK cell tolerance. J Exp Med 205: 1829-1841, 2008.

52. Pittari G, Liu XR, Selvakumar A, Zhao Z, Merino E, Huse M, Chewning JH, Hsu KC and Dupont B: NK cell tolerance of self-specific activating receptor KIR2DS1 in individuals with cognate HLA-C2 ligand. J Immunol 190: 4650-4660, 2013.

53. Shifrin N, Raulet DH and Ardolino M: NK cell self tolerance, responsiveness and missing self recognition. Semin Immunol 26: 138-144, 2014

54. Jiang K, Zhu FM, Lv QF and Yan LX: Distribution of killer cell immunoglobulin-like receptor genes in the Chinese Han population. Tissue Antigens 65: 556-563, 2005.

55. Wu GQ, Zhao YM, Lai XY, Yang KL, Zhu FM, Zhang W, Wang W, Luo Y, Tan YM, Wang YJ, et al: Distribution of killer-cell immunoglobulin-like receptor genes in eastern mainland Chinese han and taiwanese han populations. Tissue antigens 74: 499-507, 2009

56. Christiansen OB, Mohapeloa HP, Steffensen R and Jersild C: HLA-C and -Bw typing of couples with unexplained recurrent miscarriages. J Reprod Immunol 37: 63-77, 1997.

57. Ahn RS, Moslehi H, Martin MP, Abad-Santos M, Bowcock AM, Carrington M and Liao W: Inhibitory KIR3DL1 alleles are associated with psoriasis. Br J Dermatol 174: 449-451, 2016.

58. Kennedy PR, Chazara O, Gardner L, Ivarsson MA, Farrell LE, Xiong S, Hiby SE, Colucci F, Sharkey AM and Moffett A: Activating KIR2DS4 is expressed by uterine NK cells and contributes to successful pregnancy. J Immunol 197: 4292-4300, 2016.

59. Ormiston ML, Chang C, Long LL, Soon E, Jones D, Machado R, Treacy C, Toshner MR, Campbell K, Riding A, et al: Impaired natural killer cell phenotype and function in idiopathic and heritable pulmonary arterial hypertension. Circulation 126: 1099-1109, 2012

60. Komlos L, Zamir R, Joshua H and Halbrecht I: Common HLA antigens in couples with repeated abortions. Clin Immunol Immunopathol 7: 330-335, 1977.
61. Varla-Leftherioti M, Spyropoulou-Vlachou M, Keramitsoglou T, Papadimitropoulos M, Tsekoura C, Graphou O, Papadopoulou C, Gerondi M and Stavropoulos-Giokas C: Lack of the appropriate natural killer cell inhibitory receptors in women with spontaneous abortion. Hum Immunol 66: 65-71, 2005.

62. Faridi RM, Das V, Tripthi G, Talwar S, Parveen F and Agrawal S: Influence of activating and inhibitory killer immunoglobulin-like receptors on predisposition to recurrent miscarriages. Hum Reprod 24: 1758-1764, 2009.

63. Wang S, Zhao YR, Jiao YL, Wang LC, Li JF, Cui B, Xu CY, Shi $\mathrm{YH}$ and Chen ZJ: Increased activating killer immunoglobulin-like receptor genes and decreased specific HLA-C alleles in couples with recurrent spontaneous abortion. Biochem Biophys Res Commun 360: 696-701, 2007.

64. Sivori S, Carlomagno S, Falco M, Romeo E, Moretta L and Moretta A: Natural killer cells expressing the KIR2DS1-activating receptor efficiently kill T-cell blasts and dendritic cells: Implications in haploidentical HSCT. Blood 117: 4284-4292, 2011.

65. Xiong S, Sharkey AM, Kennedy PR, Gardner L, Farrell LE, Chazara O, Bauer J, Hiby SE, Colucci F and Moffett A: Maternal uterine NK cell-activating receptor KIR2DS1 enhances placentation. J Clin Invest 123: 4264-4272, 2013.

66. Dambaeva SV,Lee DH,Sung N, Chen CY, Bao S, Gilman-Sachs A, Kwak-Kim J and Beaman KD: Recurrent pregnancy loss in women with killer cell immunoglobulin-like receptor KIR2DS1 is associated with an increased HLA-C2 allelic frequency. Am J Reprod Immunol 75: 94-103, 2016.

67. Hiby SE, Regan L, Lo W, Farrell L, Carrington M and Moffett A: Association of maternal killer-cell immunoglobulin-like receptors and parental HLA-C genotypes with recurrent miscarriage. Hum Reprod 23: 972-976, 2008.

68. Flores AC, Marcos CY, Paladino N, Arruvito L, Williams F, Middleton D and Fainboim L: KIR receptors and HLA-C in the maintenance of pregnancy. Tissue Antigens 1 (69 Suppl): S112-S113, 2007.

69. Porter TF, Wong LF and Scott JR: Immunotherapy for recurrent miscarriage. Cochrane Database Syst Rev 21: CD000112, 2006.

70. Chen JL, Yang JM, Huang YZ and Li Y: Clinical observation of lymphocyte active immunotherapy in 380 patients with unexplained recurrent spontaneous abortion. Int immunopharmacol 40: 347-350, 2016.

71. Hutton B, Sharma R, Fergusson D, Tinmouth A, Hebert P, Jamieson J and Walker M: Use of intravenous immunoglobulin for treatment of recurrent miscarriage: A systematic review. BJOG 114: 134-142, 2007

72. Ata B, Tan SL, Shehata F, Holzer H and Buckett W: A systematic review of intravenous immunoglobulin for treatment of unexplained recurrent miscarriage. Fertil Steril 95: 1080-1085, 2011.

73. Liu Z, Xu H, Kang X, Wang T, He L and Zhao A: Allogenic lymphocyte immunotherapy for unexplained recurrent spontaneous abortion: A meta-analysis. Am J Reprod Immunol 76: 443-453, 2016.

This work is licensed under a Creative Commons Attribution-NonCommercial-NoDerivatives 4.0 International (CC BY-NC-ND 4.0) License. 